\title{
Diplomacia, turismo e identidad nacional: La celebración del 12 de octubre en España durante la Guerra Fría*
}

\author{
Marcela García Sebastiani ${ }^{1}$ \\ Universidad Complutense de Madrid \\ mgarciaseba@cps.ucm.es
}

RESUMEN: Las conmemoraciones y celebraciones patrióticas han sido atendidas en recientes estudios sobre el nacionalismo y las identidades territoriales. El 12 de octubre es día de fiesta nacional de los españoles desde 1987. Fue día de la raza desde 1918 y día de la hispanidad desde 1958. Perdurable y adaptada al cambio político, discrepancias regionales y coyunturas internacionales durante el siglo $X X$, la celebración hace referencia al pasado imperial para la identificación de los españoles, entre ellos y con el mundo. Este trabajo estudia cómo el turismo, en plena expansión durante el franquismo desarrollista, se incorporó a la puesta en escena y moldeó la dimensión internacional de la celebración itinerante por la geografía española, difundiendo paisajes, territorios y significados de la fecha para identidades nacionales, regionales y transnacionales. El análisis se centra en el despliegue de actores públicos y asociaciones civiles en las fiestas de 1957 y 1963 para demostrar cómo el símbolo fue un instrumento de diplomacia cultural y expresión de una idea de España en el mundo durante la Guerra Fría.

* Trabajo para el Panel «Conmemoraciones y símbolos nacionales entre España y América Latina, siglo XX», XXXVI Congress Latin American Studies Association (LASA), Barcelona, 2018. Algunas ideas fueron expuestas en el XVIII Congreso Internacional de la Asociación de Historiadores Latinoamericanistas Europeos (AHILA), Valencia, 2017. Proyecto I+D+I HAR 2016-75002-P (Gobierno de España).

Se agradecen las aportaciones de los evaluadores anónimos del artículo.

Archivo General de la Administración (AGA), Alcalá de Henares, Madrid. Archivo Juan Linz, Fundación Juan March (AJL, FJM), Madrid.

${ }^{1}$ ORCID iD: https://orcid.org/0000-0003-0869-3924.

Copyright: (C) 2021 CSIC. Este es un artículo de acceso abierto distribuido bajo los términos de una licencia de uso y distribución Creative Commons Reconocimiento 4.0 Internacional (CC-BY 4.0) 


\section{PAlabras Clave: franquismo; turismo; identidades transnacio- nales; 12 de octubre; diplomacia cultural; Guerra Fría.}

Diplomacy, tourism and national identity: the October 12 celebration in Spain during the Cold War

ABSTRACT: Patriotic celebrations and commemorations have received attention in recent studies on nationalism and territorial identities. October 12 has been the Spanish National Day since 1987. It was known first as the "Day of the Race" in 1918 and became the "Day of Hispanidad" in 1958. The celebration - which survived and adapted to political change, regional differences and international conjunctures throughout the twentieth century evokes Spain's imperial past with its identification of "Spanishness", both among Spaniards and in the world. This paper explores how tourism, in full expansion during the Francoist regime, was incorporated into the staging and shaping of the international dimension of this itinerant celebration across Spanish territory, spreading landscapes, territories and meanings for October 12, appealing to national, regional and transnational identities. The analysis focuses on the deployment of public actors and civil associations during the celebrations of 1957 and 1963 to prove how this symbol became an instrument of cultural diplomacy and the expression of an idea of Spain in the world during the Cold War.

KEY WORDS: Francoist regime; tourist; cultural diplomacy; transnational identities; October 12; Cold War.

CÓMO CITAR ESTE ARTÍCULO/CITATION: García Sebastiani, Marcela, «Diplomacia, turismo e identidad nacional: La celebración del 12 de octubre en España durante la Guerra Fría», Hispania, 81/267 (Madrid, 2021): 195-226. https://doi.org/10.3989/hispania.2021.007.

\section{INTRODUCCIÓN}

Los símbolos y las prácticas conmemorativas despuntan en los estudios recientes sobre el nacionalismo español y las identidades territoriales para la historia del siglo $\mathrm{XX}^{2}$. En tanto representaciones materiales y con resultados efectivos, las tradiciones escenificadas de la nación en espacios públicos

\footnotetext{
2 MORENO LUZÓN y NÚÑEZ SEIXAS, 2017. ALARES LÓPEZ, 2017. CAMPOS PÉREZ, 2016.
}

Hispania, 2021, vol. LXXXI, n. ${ }^{\circ}$ 267, enero-abril, págs. 195-226, ISSN: 0018-2141, e-ISSN: 1988-8368 
conformaron imaginarios y fueron todo un campo abierto para la exhibición, la socialización, la negociación y el conflicto acorde con intereses de actores sociales y políticos. Síntesis de una forma de comunicación entre el Estado y la sociedad civil, la fiesta nacional es un día clave para la memoria e identificación con un pasado y proyectos futuros en común.

El día de la fiesta nacional de los españoles es, desde 1987, el 12 de octubre. Fue día de la Raza desde 1918 y día de la Hispanidad desde 1958. La fecha sitúa la epopeya nacional española fuera de sus fronteras territoriales y coloca al descubrimiento de América y el pasado imperial como escaparate de identificación de los españoles entre ellos y con el mundo. Un referente externo define la cohesión social, funde el relato nacional, afirma tradiciones y, en tanto acto fundacional de la nación, funciona como mito disponible al servicio del poder. El festejo combina tradiciones seculares y católicas de liberales y conservadores, haciéndolas coincidir con el honor a la virgen del Pilar, patrona de Aragón, y el reconocimiento a corporaciones estatales como la guardia civil y los trabajadores de correos. El símbolo es un componente esencial más que cívico del nacionalismo español con alusiones a la religión, el orden y la comunicación nacional e internacional ${ }^{3}$.

La celebración sobrevivió al cambio de regímenes políticos, una guerra civil, diferencias territoriales y contextos internacionales. Su permanencia en el imaginario nacionalista español, aun transformando su ritual, expresa un significado poco controvertido y una fácil adaptación a diferentes ideas de nación ${ }^{4}$. Como símbolo de la tradición inventada del hispanoamericanismo, la fiesta movilizó a la sociedad civil y a las instituciones, y fue un instrumento diplomático y de proyección exterior durante el siglo XX. En parte, porque el 12 de octubre se incorporó al calendario festivo de países latinoamericanos desde la Primera Guerra Mundial y al recuerdo escenificado en ciudades de Estados Unidos desde finales del siglo XIX. Ese carácter transnacional construyó la idea de una comunidad internacional imaginada desde la empatía cultural y esfuerzos proyectivos que funcionó, con variaciones, hasta las cumbres iberoamericanas de 1991. La historia del 12 de octubre es una pieza fundamental para una historia hispánica modulada y sostenida por intelectuales, organismos públicos y privados, diplomáticos, emigrantes, y la iglesia católica. El festejo conecta política, cultura, religión, sociedad, negocios internacionales y cosmopolitismo.

Este trabajo analiza la implicación del turismo en la celebración del 12 de octubre como una fórmula de diplomacia cultural y de promoción de una idea de España durante el franquismo. Símbolo útil para la identidad nacional y transnacional, la fiesta fue un artefacto cultural y sociopolítico más de la

\footnotetext{
3 GARCÍA CÁRCEL, 2011. HUMLEBAEK, 2015.

${ }^{4}$ RODRÍGUEZ, 2004. GARCÍA SEBASTIANI y MARCILHACY, 2017.
} 
dictadura para cambiar su imagen externa y salir del aislamiento internacional tras la guerra civil. El análisis se detiene en la puesta en escena de actores e instituciones en los festejos de 1957 y 1963 para demostrar cómo el turismo, en tanto instrumento de identidad y en plena expansión para la España desarrollista, se incorporó a las políticas hispanoamericanas exhibidas cada 12 de octubre por diferentes lugares del territorio. En momentos de despolitización del nacionalcatolicismo en el espacio público y de interés por consolidar vínculos internacionales, los tecnócratas católicos gestores de las políticas exteriores, la cultura, la información, la propaganda y el turismo, diseñaron y activaron prácticas de diplomacia blanda y reformas para una apertura de España al mundo en plena Guerra Fría.

Con una función transnacional, el turismo fue clave para la diplomacia y los negocios de España con Europa, Estados Unidos y América del Sur durante el siglo XX. Fue rentable no solo para la modernización económica y social española sino también para la identificación nacional e integración internacional ${ }^{5}$. El turismo participó en la construcción de identidades nacionales, regionales e internacionales difundiendo paisajes, territorios, tradiciones e imágenes, dentro y fuera de España ${ }^{6}$. Por un lado, se pone el foco en la geografía y el nacionalismo. Por otro, en el punto de vista exterior para la imaginación política.

\section{TURISMO, FIESTA Y DIPLOMACIA DURANTE EL FRANQUISMO}

Desde el inicio de la Guerra Fría, las posibilidades del turismo generaron ideas y diálogos transnacionales entre Europa, Estados Unidos y América Latina $^{7}$. El turismo se convirtió en pieza fundamental para el entendimiento diplomático y las relaciones exteriores en el mundo de posguerra, incluso entre países capitalistas y socialistas. Impulsó el internacionalismo y fórmulas de diplomacia blanda para el mercado, organizaciones y una cultura pacifista. La publicidad ayudó a asociarlo con nuevas prácticas de sociabilidad, comunicación y coordinación internacional entre Estados, partidos políticos y sociedades civiles. La industria de los viajes diplomáticos fue paralela a los acuerdos de cooperación entre gobiernos, asociaciones y empresas del sector. Y, los visados turísticos fortalecieron relaciones bilaterales. Ámbito de diplomacia cultural y atenuante de antagonismos nacionalistas y diferencias sociales, el turismo facilitó el consumo y la estabilidad política entre Estados ${ }^{8}$.

\footnotetext{
5 MORENO GARRIDO y VILLAVERDE, 2019.

${ }^{6}$ STORM, 2013; 2014; 2019.

7 ENDY, 2004.

8 IRIYE, 1997. PACK, 2013.
}

Hispania, 2021, vol. LXXXI, n. ${ }^{\circ}$ 267, enero-abril, págs. 195-226, ISSN: 0018-2141, e-ISSN: 1988-8368 
Las clases medias y trabajadoras europeas y americanas participaron del despliegue del turismo por Europa durante los años cincuenta y sesenta. España se convirtió en destino preferente para visitantes que buscaban el sol y la playa del Mediterráneo, lo exótico y registros de herencia cultural. En plena Guerra Fría, el turismo fomentaba el crecimiento económico, el impulso al transporte y el bienestar europeo. Para las democracias del norte, garantizaba ocio y movilidad para sus ciudadanos. Para las dictaduras del sur, ofrecía modernización y riqueza para legitimar políticas no democráticas. El turismo generó crecimiento económico, impulsó el cambio social e introdujo al franquismo en circuitos internacionales cuando tenía escasos Estados amigos, facilitando el diálogo entre gobiernos, operadores de viaje, agencias de publicidad y técnicos reguladores de la aviación civil entre Europa y América9.

Propio del turismo es, por tanto, su conexión con la historia política o una historia sociocultural transnacional ${ }^{10}$. El turismo, imaginado y practicado, construyó narrativas culturales y políticas de alcance global; configuró memorias de patrimonio y consumo para identidades nacionales y transnacionales. Sus discursos y representaciones acompañaron los procesos de construcción de la identidad nacional, la modernización y la integración internacional del franquismo desarrollista. Diplomáticos, técnicos y empresarios desempeñaron sociabilidades para políticas turísticas gubernamentales incluidas en proyectos de nación. De hecho, desde comienzos de los años cincuenta se implicaron en la fiesta del 12 de octubre porque era un símbolo de definición hispana que no solo generaba viajes protocolarios y profesionales, sino que también ponía en circulación imágenes, lugares y narrativas de nación con capacidad de crear y transmitir opinión. Con criterios tecnocráticos estatales, el turismo participó en la celebración moldeando marcos modernos de interpretación asociados al símbolo para despertar la imaginación de amplias audiencias.

El franquismo había amplificado el significado del 12 de octubre. La celebración materializó una Hispanidad entendida como una comunidad internacional imaginada entre geografías, Estados, sociedades y culturas, reforzando el relato nacionalcatólico y la mitificación de un pasado glorioso y personajes heroicos. $\mathrm{La}$ dictadura renovó la idea de una identidad española prolongada en el mundo con América como signo de prestigio nacional y herencia transnacional. Y construyó su imagen exterior, la propaganda y la memoria desde la nostalgia de un imperio que había hecho grande, civilizada y unida a la nación española centralizada desde Madrid como capital del Estado ${ }^{11}$. Ese imaginario también se acopló a los planes de regeneración interna para encajar la diversidad territorial en las

\footnotetext{
${ }^{9}$ CRUMBAUGH, 2009.

${ }^{10}$ LARRINAGA y VALLEJO POUSADA, 2013.

${ }^{11}$ GONZÁLEZ CALLEJA y LIMÓN NEVADO, 1988. DELGADO GÓMEZ-ESCALONILLA, 1992.
} 
tradiciones nacionales. La idea que enfundaba la celebración se institucionalizó desde 1945 con plataformas administrativas para la política exterior como el Instituto de Cultura Hispánica (ICH) y la Dirección General de Relaciones Culturales del Ministerio de Asuntos Exteriores, desde donde se orquestaba el despliegue político y cultural hacia América ${ }^{12}$.

Durante la década del cuarenta, el franquismo había reforzado los símbolos de la identidad nacional confiando el uso y la rutina del recuerdo público a la ofensiva cultural y diplomática del nacionalcatolicismo. Madrid y Zaragoza habían acaparado el culto laico y religioso del 12 de octubre en los años posteriores a la guerra civil para asegurar lealtades, dentro y fuera de España. En Madrid, el día se reservaba para homenajes e inauguraciones solemnes de edificios reconstruidos por el nuevo Estado. El componente religioso lo ponían las misas ofrecidas a su patrona, la virgen del Pilar, por los trabajadores estatales de correos y la guardia civil ${ }^{13}$. En la ciudad aragonesa, cada 12 de octubre se escenificaba el arraigo de la cultura religiosa local en las tradiciones nacionales y transnacionales del culto hispánico a la virgen del Pilar. Entronada como embajadora de la Hispanidad y de misiones caritativas en el exterior desde 1941, el símbolo religioso identificaba una forma de comunicación con una familia de naciones desde una geografía singular y a partir de registros católicos que fomentaban el intercambio de herencias culturales y una unidad imaginada $^{14}$ : En todo caso, Zaragoza fue una de las geografías promovidas por el catolicismo español como nexo de internacionalismo. Desde los años cuarenta, el franquismo también había mostrado interés por hacer de la peregrinación al sepulcro del santo de Santiago de Compostela, iniciada a finales del siglo XIX, un itinerario simbólico y cultural para animar los viajes de los amigos del régimen, el internacionalismo católico y el prestigio español entre los europeos ${ }^{15}$.

El franquismo también había incluido los festejos del 12 de octubre en el embate de la diplomática pública y propagandística hacia afuera. Las embajadas, especialmente en Argentina y Estados Unidos, desplegaron con la celebración todo un protocolo de relaciones públicas y de empeño institucional para renovar las prácticas comerciales y de seducción política. Se recurría a la nostalgia y la herencia cultural para reunir adeptos a la imaginación de una amplia familia hispánica entre políticos, intelectuales y sectores de la sociedad civil interesados en movilizar iniciativas y recursos de una identidad transnacional. La administración del turismo, que durante la década del cuarenta estuvo relacionada con la de prensa y propaganda del Ministerio del Interior, se sumó a la estrategia del poder blando, sutil y persuasivo del franquismo para impulsar

\footnotetext{
12 ESCUDERO, 1994.

13 BARRACHINA, 1999-2000. ABC (Madrid), 13.10.1944 y 12-13.10.1946.

14 CENARRO, 2003. RAMÓN SOLANS, 2014.

15 PACK, 2010.
} 
contactos con el mundo ${ }^{16}$. Después de todo, los visitantes y espectadores animados por políticas gubernamentales podían convertir al turismo no solo en instrumento útil para la política exterior, sino también para la definición de una identidad turística nacional española. La fiesta apenas provocaba fricción diplomática entre sus invitados dentro y fuera de España. Los viajes institucionales y culturales fomentaban entendimientos transnacionales, y creaban espacios únicos y perpetuos para el mercado internacional y la difusión de identidades regionales y nacionales ${ }^{17}$.

Para eso, el franquismo había promovido contactos para negocios, campañas publicitarias, la apertura de oficinas españolas de turismo, viajes de políticos y reuniones empresariales. Desde los años cuarenta había sido prioridad establecer relaciones con Estados Unidos y Gran Bretaña, donde el turismo de masas estaba organizado y se utilizaba para la política internacional. Se intentó con Argentina y las cosas no fueron sencillas. Los negocios resultantes del turismo norteamericano fueron más fructíferos y despuntarían en la década de 1960. En plena Segunda Guerra Mundial, la secretaría de turismo del régimen formuló planes financieros para construir hoteles, conservar parques y tesoros artísticos, e impulsar el transporte y rutas de peregrinación religiosa como nexos para el intercambio viajero ${ }^{18}$. También se registraron agencias de viajes extranjeras y se facilitaron los servicios para rutas internacionales y desplazamientos diplomáticos y empresariales organizados hacia destinos únicos de América Latina y Estados Unidos ${ }^{19}$. Desde 1946 se regularon los vuelos comerciales entre Madrid y Buenos Aires, y entre Nueva York y Madrid mientras se abrían oficinas de turismo. Completaron el acercamiento nuevas sedes abiertas en Londres, Roma y Estocolmo, acuerdos para el tráfico aéreo, y leves alivios al proteccionismo ${ }^{20}$.

El empeño de incluir al turismo entre las políticas exteriores fomentó el viaje de personalidades ilustres para quienes se diseñaban programas de actividades por la geografía nacional española. Por ejemplo, el realizado por Eva Perón en 1947 o el de periodistas y editores norteamericanos, cubanos y mexicanos invitados por el régimen en 1950. También hicieron excursiones por el territorio nacional empresarios hosteleros de 136 países reunidos en un congreso internacional entre el 5 y el 15 de octubre de 1948. Promovida para las celebraciones del 12 de octubre, la actividad disponía del símbolo de identidad nacional y transnacional. Por su parte, el turismo se adaptó al programa del evento para fomentar su industria y ponerla al servicio del sostenimiento del

\footnotetext{
${ }^{16}$ NYE Jr., 2004; 2011.

17 ZUELOW, 2010.

18 PACK, 2009: 66-68; 2010.

19 WARD, 2008.

${ }^{20}$ PACK, 2009. ROSENDORF, 2014.
} 
régimen. Esos viajes hacían publicidad y difundían una imagen diversa de España y amable del franquismo destinada a la opinión y la llegada de posibles turistas ${ }^{21}$.

Por tanto, el turismo había planeado en las decisiones políticas del franquismo para salir del aislamiento internacional, sorteando espacios para el intercambio de bienes y servicios durante la posguerra. Con una modesta cuota en el mercado mundial, se lo entendió como un dispositivo para la práctica social, comercial y de entendimiento cultural entre países ${ }^{22}$. Los empresarios amigos del régimen se adaptaron a las demandas de turistas americanos y europeos. Desde la administración se urdieron negocios con líneas aéreas y otros sectores vinculados al turismo en Europa y América, como la edición de guías viaje, revistas y periódicos consumidos por las clases medias en expansión. Como paso clave, España entró en organizaciones europeas de turismo ${ }^{23}$.

Dado que el sector estaba cambiando a España se creó el Ministerio de Información y Turismo (MIT) en 1951, tras una crisis de gobierno. Desde allí, se activó una campaña para mejorar la imagen externa del régimen y ensalzar lo específico del atractivo español. El eslogan «Spain is beautiful and different» combinaba propaganda política y turística para multiplicar iniciativas empresariales con Europa, Estados Unidos y América del Sur. Empeñado por encontrar amigos internacionales, el franquismo enfatizó las tradiciones históricas y culturales, y el tipismo de las regiones; un campo neutro, banal y despolitizado ideal, que interesaba a turistas, empresarios y diplomáticos ${ }^{24}$. En los años cincuenta, el régimen conservador y autoritario incluyó también a una Iglesia menos beligerante en los planes de modernización vinculados tanto al negocio del turismo como a la construcción de una identidad turística nacional con singularidades culturales de la geografía española útiles para la diplomacia y el prestigio internacional. La intervención del Estado en la promoción de alojamientos y rehabilitación de edificios históricos y artísticos para el Camino de Santiago, por ejemplo, había potenciado al turismo asociado a un símbolo cultural europeo para el catolicismo transnacional ${ }^{25}$.

Si el turismo facilitaba el crecimiento económico y la consolidación política del régimen, su inclusión en el recorrido para las fiestas el 12 de octubre reforzó no solo el significado simbólico de una identidad española que se prolongaba en el mundo sino también el de los lugares elegidos por el ICH para desplegar el ritual. Desde los años cincuenta, la celebración se había hecho itinerante por la geografía española. Su puesta en escena se transformaba cada año. El

\footnotetext{
${ }^{21}$ CORREYERO RUIZ, 2003.

22 VALLEJO POUSADA, 2015.

${ }^{23}$ PACK, 2009: 86-90 y 96. ROSENDORF, 2014, cap. 3.

24 AFINOGUÉNOVA, 2017. STORM, 2013.

${ }^{25}$ PACK, 2010.
}

Hispania, 2021, vol. LXXXI, n. ${ }^{\circ}$ 267, enero-abril, págs. 195-226, ISSN: 0018-2141, e-ISSN: 1988-8368 
impulso del turismo y la diplomacia pública ofrecieron nuevas ideas sobre cómo y dónde celebrarla. El protagonismo recayó en las autoridades, las fuerzas vivas locales y regionales, la Iglesia, los cuerpos de la administración algo renovada y la diplomacia amiga del régimen. Escenario de exhibición de la sociabilidad honorable, la fiesta era un instrumento más de propaganda que avivaba el imaginario nacionalista español y contribuía a la definición nacional para un público internacional. El ritual ensalzaba al cuerpo representativo que participaba de la invención de una comunidad imaginada de países iberoamericanos ${ }^{26}$.

Aunque Madrid acogiera ocasionalmente el festejo institucional, cada 12 de octubre se conmemoraba en una ciudad española diferente. En la imaginación de los organizadores pesaba el significado simbólico e histórico de los lugares revalorados en relación con el descubrimiento de América, la emigración, el americanismo asociativo, o la monarquía hispánica. Con la incorporación a la fiesta viajante de las políticas turísticas en plena expansión se atendía asimismo a la promoción de espacios emblemáticos de la geografía española que habían atraído la inversión estatal y privada para el turismo de sol y playa sin renunciar a la exhibición de los registros de herencia cultural para turistas europeos, americanos y nacionales. Cada año, el régimen remozaba la interpretación que los territorios tenían con la fiesta y la nación. Los sitios del ritual itinerante servían como referentes de una identidad nacional española en términos de diversidad cultural y geográfica más que política; de folklore, patrimonio y naturaleza. En los años cincuenta y sesenta, la fiesta estaba disponible tanto para la urgencia de coyunturas como para proyectos más abarcadores; servía como elemento aglutinador de la complejidad territorial de la nación y atajaba malestares de un excesivo centralismo estatal.

Durante las fiestas del 12 de octubre en Las Palmas de Gran Canaria en 1957, Mallorca en 1960 y Tarragona en 1963, el turismo se dispuso para la definición de la identidad nacional española y la diplomacia cultural, ampliando los márgenes de políticas gubernamentales de orientación hispanoamericana ${ }^{27}$. Entonces, la celebración que removía registros culturales se aprovechó para la atracción de visitantes y la promoción de una España diversa, católica y tradicional, pero a su vez adaptada a la modernización y el turismo de masas en geografías emblemáticas y de climas benignos. Como otros símbolos de identidad nacional española y sin renunciar a rutinas y tradiciones, esos 12 de octubre contribuyeron al intercambio y a la fabricación de un perfil turístico.

\footnotetext{
26 STAVANS y JAKSÍC, 2011. SEPÚLVEDA MUÑOZ, 2005.

27 GARCÍA SEBASTIANI, 2016.
} 


\section{El 12 de octubre de 1957, entre Barcelona, Canarias y Madrid}

En 1957, Barcelona, Madrid y Las Palmas de Gran Canaria acogieron la puesta en escena institucional del 12 de octubre. No era habitual tanto despliegue por el territorio nacional para la fiesta. Se había movilizado, incluso, a embajadas españolas en Europa, Estados Unidos y América Latina, activando opiniones y relaciones públicas entre diplomáticos, periodistas, políti$\cos$ influyentes y asociaciones de emigrantes mediante recepciones, suplementos extraordinarios de prensa pagados, homenajes florales a monumentos de Colón y otros actos ${ }^{28}$. En 1957, en España la fiesta escenificó el ensayo de soluciones en favor de algún reconocimiento a la diversidad territorial, nuevas políticas exteriores y las posibilidades del turismo en medio de incompatibles proyectos de nación, ambos antiliberales y antidemocráticos, que arrastraban falangistas y católicos tras la guerra civil y que habían saltado por los aires un año antes ${ }^{29}$.

La fiesta se había salpicado de la tormenta política tras las revueltas estudiantiles y de trabajadores que habían estallado en 1956 por ciudades españolas. La crisis internacional desatada por la independencia de Marruecos había exacerbado el clima de inestabilidad política. La formación de un nuevo gobierno, en febrero de 1957, apaciguó las diferencias de familias de la dictadura, enzarzadas por ocupar espacios políticos tras aprobar una nueva ley de régimen jurídico para el Estado. Unas se negaban a renunciar al control de la administración y otras se empeñaban en modernizarla desde las entrañas para hacerla eficaz. Entre ambas, los católicos intentaron sobrevivir en la gestión institucional. Tras años de servicio a la dictadura, muchos desaparecieron y, quienes no encontraron encaje, se refugiaron en el ICH y otros enjambres corporativos. Los tecnócratas, la mayoría vinculados al Opus Dei, habían resuelto la crisis y dispusieron de nuevas políticas y personal para la dictadura ${ }^{30}$.

El 12 de octubre se adaptó a esa salida política. Tras el aterrizaje del nuevo equipo de tecnócratas católicos, el ICH recicló la celebración. Se consolidó el ritual itinerante y se reforzó su carácter civil e institucional sin restar protagonismo a la Iglesia católica y a la diplomacia. Acompasó la nueva etapa del franquismo, abierta al desarrollo económico, el turismo y una política exterior promotora de ilusiones e intereses internacionales como fórmula preventiva del comunismo en plena Guerra Fría. El símbolo se adecuó a la diplomacia blanda, ayudado por la progresiva despolitización de la religión en las tradiciones escenificadas para el 12 de octubre en Zaragoza, donde la fiesta había pasado a

${ }^{28}$ Mundo Hispánico (Madrid), 116, 1957: 7-11. ABC, 13.10.1957: 48-50.

29 BOX, 2013. SAZ, 2007.

${ }^{30}$ FERRARY, 1993. RUIZ CARNICER, 1996. JULIÁ, 2004: 355-407. HISPÁN IGLESIAS DE USSELL, 2006: 13-169. 
formar parte del acervo folklórico y cultural con ofrendas florales a la virgen del Pilar ${ }^{31}$.

También había sido clave la incorporación del MIT al andariego festejo. En su empeño por promocionar el carácter exótico y diferencial de España en el mundo y atraer sensibilidades de clases medias americanas y europeas en plena eclosión, el turismo, la cultura de lugares emblemáticos y el recuerdo conmemorativo dulcificaban la política exterior del régimen. La celebración se impulsó, incluso, en espacios periféricos del Mediterráneo y del Atlántico, como Mallorca o Tarragona, o las islas Canarias, abiertos a la invasión pacífica de turistas y empresarios del sector. Después de todo, la habilidad del franquismo permitía que la modernidad y su proyección internacional no fuera incompatible con las esencias hispánicas, el nacionalismo o el nacionalcatolicismo.

La diplomacia pública, liderada desde 1957 por Fernando Castiella desde el Ministerio de Exteriores, venía ensayando mecanismos para integrar el 12 de octubre en las políticas culturales de España hacia afuera, involucrando a embajadas, consulados y asociaciones civiles. Los acuerdos económicos, militares y políticos firmados con Estados Unidos y El Vaticano, en 1953, y el ingreso en la ONU, en 1955, habían mejorado la imagen del franquismo ${ }^{32}$. Progresivamente, se fueron normalizando las relaciones exteriores, aunque marginadas de los proyectos de integración europea. Como solución, Castiella y su equipo habían ideado una imaginada comunidad iberoamericana como ámbito de convivencia con América Latina, Portugal y Filipinas ${ }^{33}$. Componente cultural del nacionalismo español, el 12 de octubre quedó asociado al programa global de modernización diplomática del franquismo durante los años sesenta.

Las novedades del festejo coincidieron, por tanto, con un recambio generacional en la administración y el diseño de una incipiente política exterior. El turismo se había sumado a una celebración eficaz para definir la identidad nacional con complementos de tradiciones locales y regionales. Capitales de provincia con costumbre en el homenaje o con nuevos intereses en la movediza conmemoración pujaban por los actos institucionales. Para su recorrido por la geografía española, el régimen compuso la idea de una nación diversa, aunque centralizada e integradora de élites periféricas leales y promotoras de identidades regionales y locales. La fórmula sirvió para aglutinar regionalismos y atajar los desafíos de nacionalismos periféricos y el antifranquismo de determinados territorios. El pragmatismo político se aderezó al ritual de una fiesta regionali$\mathrm{zada}^{34}$. Autoridades provinciales, regionales, académicas, el Ejército y otras fuerzas del orden, la Iglesia, diplomáticos, gestores culturales y empresarios

\footnotetext{
31 RAMÓN SOLANS, 2014.

32 PARDO, 2000.

33 ARENAL, 1994.

${ }^{34}$ GARCÍA SEBASTIANI y MARCILHACY, 2017.
} 
estaban presentes en la puesta en escena de cada 12 de octubre. Se invitaba a embajadores de América Latina, Estados Unidos, Filipinas y Portugal. En los actos principales participaban los ministros de Exteriores y Educación, y el director del ICH. En ocasiones, asistía el propio Franco, generando consensos, fobias y miedos.

Franco, su mujer y el ministro de Educación — Jesús Rubio - viajaron a Barcelona para el 12 de octubre de 1957 y para presidir en el histórico Salón de Ciento del Ayuntamiento la clausura de un congreso interamericano de historia municipal. Ya en 1955 el dictador había animado la celebración en la ciudad. Pero esta vez, acompañados de autoridades civiles y militares, se dejaron ver desde días antes haciendo compras, despachando desde el Palacio de Pedralbes y asistiendo a actos culturales y a un partido de fútbol entre los clubes de Barcelona y de Sevilla. Aun siendo día laborable, en la tarde del 10 de octubre los especiales visitantes habían sido ovacionados por las masas delirantes mientras se dirigían al palco alfombrado y adornado con flores, gallardetes y banderas nacionales ${ }^{35}$.

Acudir personalmente y hacerse notar en la plaza de Sant Jaume habían sido decisiones políticas a la vista del anterior viaje a la ciudad, en junio de 1957. Desde el final de la guerra civil, la dictadura estaba obsesionada por atajar en Cataluña la desafección política por parte de la sociedad y los asiduos problemas por el poder entre la diputación, el alcalde y el gobernador civil en Barce$\operatorname{lona}^{36}$. Y se recurría al fomento de obras públicas y a la propaganda política. Especialmente, en la ciudad de Barcelona, las aversiones a la dictadura habían resurgido con fuerza en 1956 sacando a los estudiantes a la calle. La cosa pareció solucionarse apoyando la designación por Franco de José M. Porcioles como alcalde de la ciudad y prometiendo al catalanismo moderado medios jurídicos, económicos y simbólicos para resolver los problemas políticos y contener la inquina social al régimen ${ }^{37}$.

No fue casual que la ciudad de Barcelona haya sido elegida para el cierre de reflexiones sobre la historia municipal e impregnar la memoria del 12 de octubre. Todo proyecto republicano, liberal, radical o autoritario - como el franquismo - disponía del cuerpo doctrinal del municipio para la acción política y gestión administrativa. Desde allí arrancaban las iniciativas descentralizadoras o intervencionistas del Estado, las propuestas federales o unitarias. El municipio era el espacio desde donde se forjaba nación desde abajo a arriba, de la periferia al centro; desde donde se configuraban lealtades e identidades locales. Modelo con referencias históricas en Europa y América, en su organización se fundían intereses sociales e institucionales ${ }^{38}$.

\footnotetext{
${ }^{35}$ La Vanguardia (Barcelona), 11.10.1957.

36 TÉBAR, RISQUES, MARÍN y CASANELLAS, 2015: 1-184.

${ }^{37}$ MOLINERO e YSÁS, 2014. HISPÁN IGLESIAS DE USSEL, 2006.

${ }^{38}$ DUARTE, 2006.
} 
Desde los años cuarenta, la dictadura buscaba fórmulas sobre cómo gobernar las ciudades. De hecho, como municipios mayores del Estado, tanto Barcelona como Madrid reclamaban un régimen jurídico especial de administración local. Como solución, desde el poder se organizaban reuniones de expertos y se ofrecía la democracia orgánica donde la familia, la corporación local y el sindicato servían de base para la representación política. La nueva gestión municipal de Porcioles en Barcelona proponía algunos cambios, todos distantes de elecciones democráticas como ejercicio de soberanía y de formación de gobiernos. También lo fueron las disposiciones exclusivas establecidas para Barcelona y Madrid en 1960 y 1963, respectivamente ${ }^{39}$.

El interés del franquismo por incorporar a Cataluña al proyecto nacional, exhibido para el 12 de octubre, recogía singularidades políticas del territorio como testimonio de la diversidad. Para la celebración de 1957, sin embargo, el tema municipal era un pretexto para promocionar los apoyos del régimen al nuevo alcalde de Barcelona. De hecho, el congreso municipal tenía un carácter interamericano e histórico que había reunido en Madrid desde el 5 de octubre a los amigos internacionales del régimen y a alcaldes de ciudades españolas a iniciativa de un Instituto de Administración Local, la Universidad de Madrid y el ICH que insistió en implicar a Franco en los actos que, en un principio, no incluían la visita a la ciudad ni la invitación a representantes de Gerona, Tarragona o de la misma Barcelona. Los ponentes se oyeron entre sí sobre el municipio en América y España en la Historia Moderna y fueron agasajados con corridas de toros y paseos por la ciudad, El Escorial, el Valle de los Caídos y el Museo del Prado. El alcalde de Barcelona los invitó a visitar la ciudad y su desarrollo industrial, y asistir a la celebración del 12 de octubre ${ }^{40}$.

Los actos oficiales habían comenzado en Barcelona con la tradicional ofrenda del cuerpo consular y las autoridades locales al monumento de Colón. Ese año se habían sumado los alcaldes de las provincias españolas, representaciones militares y de cámaras de comercio, asistentes del congreso municipal y el embajador de Estados Unidos, John Davis Lodge, como primer acto del XXVII Congreso Mundial de la Asociación Americana de Agentes de Viaje (ASTA) que albergó Madrid los días siguientes ${ }^{41}$. Tanto despliegue en Barcelona para el 12 de octubre había animado en la víspera especialmente a los aragoneses que vivían en la ciudad, a la guardia civil y al cuerpo de correos. Con bailes de jota y cantos

${ }^{39}$ BOE, 151, 24.06.1960: 8.685-8.694 у BOE, 171, 18.6.1963: 10.982-10.992, GIMÉNEZ MARTÍNEZ, 2014: 405-411.

${ }^{40}$ Crónica del VI congreso histórico..., 1958. Noticia histórica sobre Villa y..., 1955. AGA, Asuntos Exteriores, Gabinete diplomático, caja 82/13572, Organización de Estados Americanos, Congreso de Municipios Hispanoamericanos y Conferencia Económica Interamericana, 1957.

${ }^{41}$ Mundo Hispánico, 116, 1957: 5-6. 
folklóricos de unos, y en caravanas de coches y motos de otros, honraron con una misa a la imagen de la virgen de El Pilar en la iglesia de la ciudad, acabando con un festival popular en la Plaza de Sant Jaume ${ }^{42}$.

En el Salón de Ciento, Franco estuvo rodeado de las autoridades de Madrid y Barcelona: sus alcaldes, gobernadores civiles y presidentes de las diputaciones provinciales. También participaron de la protocolaria reunión el arzobispo de la ciudad y los diplomáticos. En el trayecto en coche, Franco había recibido salvas de aplausos hasta ser recogido, ya caída la tarde, por Porcioles en la plaza de Sant Jaume, engalanada de banderas y gallardetes. Horas antes, había sido recibido en la Plaza Monumental, atestada de gente y adornada con tapices, colgaduras y escudos. Entre el público y los aficionados a los toros, los representantes del poder, los congresistas municipales y diplomáticos participaron de una corrida benéfica en favor de viviendas a viudas, huérfanos y militares ${ }^{43}$.

En Barcelona, la fiesta escenificó al Estado benefactor y reconstructor de la ciudad para asegurar apoyos, nacionalizar y socializar a niños y jóvenes con valores jerárquicos, incluidos los de género, con toda la parafernalia simbólica activada habitualmente por el régimen para las visitas por la geografía española. Acabado el protocolo organizado para el 12 de octubre, Franco inauguró, con su mujer y otras autoridades, las instalaciones a las afueras de la ciudad de los Hogares «Anna Gironella de Mundet», impulsadas por la Diputación de Barcelona para alojar a menores huérfanos de familia o sin recursos. En el pabellón de niños, el matrimonio fue recibido por un regimiento de infantería. La bandera rojigüalda y el himno nacional pusieron color y sonido al acto mientras se pasó revista a las tropas. En el pabellón de niñas se departieron discursos ante pequeños y ancianos acogidos en la institución y educados por religiosos salesianos. Los curas amigos del régimen bendijeron el lugar adornado con flores, tapices y el escudo nacional. Franco vistió de honor a la corporación con la medalla de la Gran Cruz de Beneficencia antes de recorrer el comedor, los dormitorios, las aulas de estudio, los talleres de oficios y una efímera exposición. El periplo se completó con la visita al monasterio de Montserrat, todo un símbolo de patrimonio religioso del catalanismo desde finales del siglo XIX y destino habitual de Franco para atraer apoyos en la región. El despliegue de tanta propaganda política preveía incluso un consejo de ministros del gobierno autoritario que finalmente no se reunió ${ }^{44}$.

Las Palmas de Gran Canaria fue el segundo escenario del 12 de octubre de 1957. El ministro Castiella representaba al gobierno que había convocado con entusiasmo una reunión de embajadores iberoamericanos y autoridades del ICH para la

\footnotetext{
${ }^{42}$ La Vanguardia, 12.10.1957.

43 La Vanguardia, 13.10.1957.

${ }^{44} A B C, 15.12 .1957$ y 16.12.1957. La Vanguardia, 15.10 .1957$.
} 
ocasión. Si bien existía tradición entre los americanistas canarios en recordar la fecha desde comienzos del siglo XX, las islas no habían participado hasta entonces de la fiesta oficial ambulante. La idea había surgido del Cabildo insular y la corporación municipal interesada por ser anfitriona. La independencia de Marruecos, en 1956, había disparado las intenciones políticas en favor de la celebración en las islas Canarias para identificar el territorio periférico con la nación y el Estado. Las calles de Las Palmas se vistieron de flores para recibir a los visitantes con color y alegría. El lugar tenía la carga simbólica para reavivar el americanismo de las islas e incorporarlo como otro aporte singular a la identidad nacional española. Por su posición estratégica, Las Palmas había sido el último puerto visitado por Colón antes de viajar a América. Con la celebración se anunciaron planes para renovadas relaciones políticas entre España y América. Arropado de diplomáticos y autoridades, Castiella presentó la idea regenerada de una comunidad internacional imaginada de naciones iberoamericanas, basada en la cultura y proyectos de desarrollo económico, incluido el turismo como industria en alza en plena Guerra Fría.

Fото 1. 12 de octubre en Las Palmas de Gran Canaria, 1957

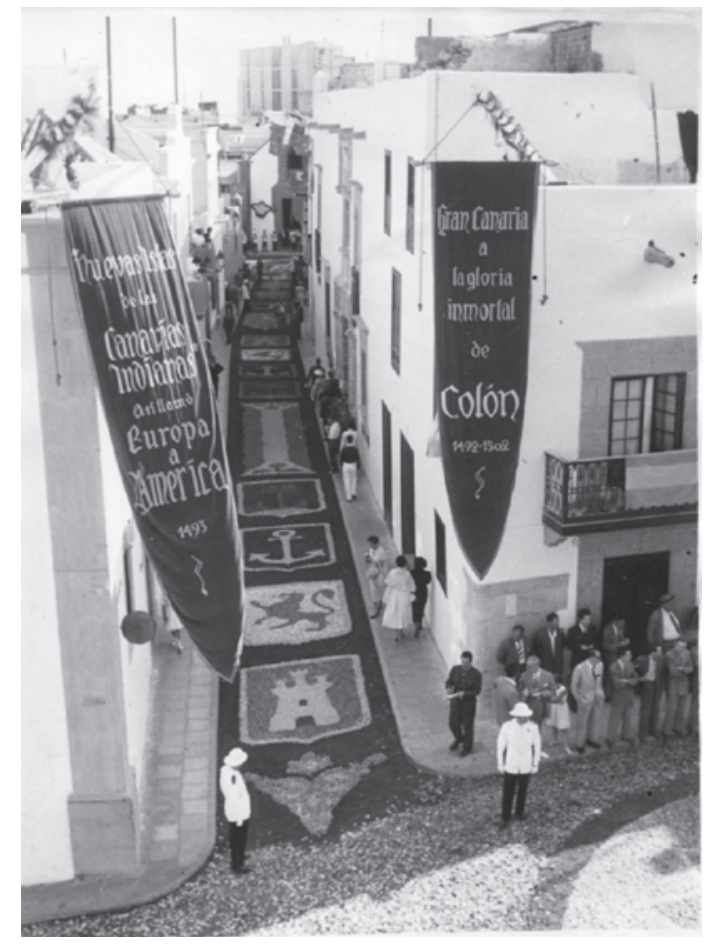

Fuente: Archivo Fotográfico Mundo Hispánico, Agencia Española de Cooperación Internacional para el Desarrollo, Biblioteca.

Hispania, 2021, vol. LXXXI, n. ${ }^{\circ}$ 267, enero-abril, págs. 195-226, ISSN: 0018-2141, e-ISSN: 1988-8368 https://doi.org/10.3989/hispania.2021.007 
Como era habitual, la religión se coló en la celebración y se ofreció una misa en memoria de Colón en la ermita de San Antonio Abad, donde el navegante había hecho los oficios religiosos antes de su aventura americana. Como homenaje cívico habitual, su monumento tuvo ofrenda floral. Para ese 12 de octubre de 1957 había hecho especial ruido el discurso de Castiella en el acto académico dispuesto en el Patio de Armas de la Casa Colón de Las Palmas, ante autoridades, embajadores y un estimable público femenino ${ }^{45}$. Relajado el aislamiento internacional, presentó el proyecto de la nueva tecnocracia católica en el poder para potenciar la imagen y la política exterior española.

Tras valorar el espacio insular como lugar de engarce entre Europa, América y África, su discurso animó a dar forma jurídica a una comunidad de naciones hispánicas, incorporando a Portugal e invitando a Estados Unidos. La idea se presentaba como un desafío a la expansión comunista en América Latina sin restar el protagonismo de España en la región y, a la vez, facilitando el establecimiento de posibles puentes con Europa. El relato retrospectivo asociado al catolicismo y al componente civilizador de España en América, propio de una idea conservadora de nación española, rezumó en las intenciones de Castiella. Los representantes de las dictaduras de Portugal y Venezuela accedieron. Los primeros, mostrando disponibilidad para esa comunidad internacional imaginada y los segundos, celebrando el pragmatismo de cada 12 de octubre para la vida internacional y el intercambio de profesionales, académicos y estudiantes ${ }^{46}$.

Por fin, el 12 de octubre de 1957 en Las Palmas se orquestó para la construcción y difusión de identidades regionales como partes integradas en una unidad nacional más amplia. Desde el Estado se incorporó la celebración en el turismo, la industria del desarrollismo. El MIT, en manos de tecnócratas católicos, exhibió con la fiesta el patrimonio cultural y ambientes únicos de las islas para el ocio internacional y moderno de clases medias que planificaban sus vacaciones. Desde los años cincuenta, el turismo había despuntado en las islas a partir de turoperadores británicos que organizaban vuelos y excursiones en lugares exclusivos a precios asequibles ${ }^{47}$. El turismo encajaba en los planes del régimen para salir del aislamiento internacional. La publicidad, controlada por la misma administración, se orquestó para incrementar la llegada de visitantes. Y la legislación pretendía ordenar el turismo por el territorio nacional, regulando las condiciones para los promotores ${ }^{48}$.

${ }^{45}$ Mundo Hispánico, 116, 1957: 7-11. ABC, 13.10.1957: 48-50.

${ }^{46}$ Fernando Castiella, Conmemoración de 12 de octubre en Canarias, 1957, AGA, Asuntos Exteriores, Dirección General de Política Exterior (en adelante, DGPE), expediente R. 5012/70.

47 PACK, 2009.

${ }^{48}$ MORENO GARRIDO, 2007.

Hispania, 2021, vol. LXXXI, n. ${ }^{\circ}$ 267, enero-abril, págs. 195-226, ISSN: 0018-2141, e-ISSN: 1988-8368 https://doi.org/10.3989/hispania.2021.007 
Mientras los diplomáticos amigos del régimen participaban del producto cultural, la fiesta se sumaba al fomento del turismo y la imagen exterior española. Celebrando el 12 de octubre en Canarias se identificaba a una región exótica, con sol saludable, playas amplias, aguas cálidas y la brisa del Atlántico como parte de la diversidad y la esencia nacional e hispánica. Lugares auténticos y únicos quedaron expuestos a la influencia internacional y nacional; al gusto de visitantes extranjeros y la difusión del negocio del turismo exclusivo entre Estados y sociedades. Después de todo, los diplomáticos y sus acompañantes no eran neutros para propagar percepciones, ideas e invenciones culturales y políticas. Para ellos, como si fueran turistas, se dispuso la fiesta para construir y divulgar identidades colectivas. También, para los españoles que iban al cine y se imaginaban la diversidad nacional desde los espacios publicitarios.

El NODO, el noticiero oficial del régimen, promocionó a las islas Canarias como espacio turístico para el 12 de octubre de 1957. Desde sus butacas, los espectadores de la gran pantalla podían imaginar vacaciones en un entorno de naturaleza idílica, paisajes únicos y patrimonio natural vistos desde el Parador de la Cruz de Tejeda en Las Palmas de Gran Canaria. El hotel, edificado por el Estado para el desarrollo del turismo de las islas, alojaba a embajadores y autoridades para la ocasión. La imagen proyectada del propio Castiella, con cámara fotográfica en mano y admirando el paisaje panorámico, animaba los viajes ${ }^{49}$. Toda una exhibición de la diversidad para ampliar la oferta turística y asegurar la idea de una nación en vías de progreso y modernización. Tanto despliegue para la celebración había desbordado los gastos del cuerpo diplomático y su séquito de funcionarios, esposas y periodistas ${ }^{50}$.

En Madrid, el tercer foco institucional del 12 de octubre de 1957, la fiesta se recicló especialmente para un nacionalismo desarrollista. Como era costumbre, la efeméride animó (o ensombreció) la imaginación de los oyentes de radio en la capital, cuyos programas recordaban la empresa ultramarina como la gloria nacional española. Como era tradición, el cuerpo de la guardia civil, acompañado de ministros del Ejército y la Marina, ofreció una misa a la virgen del Pilar en la iglesia de San Francisco el Grande. Y, el de correos, en la de los Jerónimos. También, como era habitual cada 12 de octubre, el monumento de Colón recibió coronas de flores. Esa vez, las puso el embajador norteamericano quien había participado del mismo homenaje en Barcelona, acompañado de representantes internacionales expertos en turismo. El simbolismo se amplificó con coloridas banderas de España y Estados Unidos, aludiendo a un futuro de negocios.

En efecto, en Madrid, la fiesta se dispuso para los profesionales del turismo que traerían la modernización de los españoles. La ciudad fue sede, entre el 13 y 20 de octubre, de la XXVII asamblea anual de los profesionales de la ASTA,

\footnotetext{
49 «12 de octubre», http://www.rtve.es/filmoteca/no-do/not-772/1486694/

50 Gastos de la fiesta 1957/60, AGA, DGPE, legajo 5929/3, 1960.
} 
por entonces con 3.000 miembros que movían la industria del turismo por el mundo. La diplomacia cultural enfundada con la celebración encajaba el pragmatismo político y la vía internacional de los negocios del turismo. Ya en 1925, 1928 y 1934, Sevilla, Madrid, Barcelona y Mallorca habían acogido congresos internacionales de agencias de viaje ${ }^{51}$. La reunión de 1957 fortalecía a la derecha tecnocrática frente a la católica y autoritaria, con menguado poder desde la crisis política de 1956.

Los acuerdos firmados con Estados Unidos en 1953 habían previsto la reunión que se concretó con la publicidad convenida por el franquismo para generar buena opinión y un círculo mayor de relaciones públicas externas. La industria americana del turismo estaba preparada para el despliegue organizado por el gobierno autoritario del congreso en Madrid para los festejos del 12 de octubre de 1957. En el empeño se había lucido el embajador norteamericano. La convención servía como incentivo para la participación del MIT en empresas de regeneración nacional. Para la ocasión, habían llegado a Madrid cerca de 2.000 delegados de la ASTA, algunos con sus mujeres, que consumieron por la ciudad durante una semana. La reunión internacional permitía mostrar el atractivo turístico de España y su normalidad institucional sin ser una democracia. El hotel Castellana Hilton, inaugurado en 1952 y sede de las reuniones, fue foco de atención de reporteros, escritores y editores de guías de viaje. La celebración enfundaba a Madrid de imágenes de modernidad. Para la ocasión, se inauguró el edificio Torre España en un lateral de la Plaza de España; toda una expresión de arquitectura moderna para la época. Y el Ayuntamiento de Madrid, los taxistas y la Compañía Telefónica habían llegado a un acuerdo inaugurando por fin el servicio de petición de taxis por teléfono ${ }^{52}$.

La reunión comenzó con solemnidad en el Palacio de la Música de la Gran Vía madrileña con ministros, embajadores, directores de asociaciones, empresas de turismo y de transporte, y delegados de agencias de viajes de Estados Unidos, Canadá y otros 64 países. Todos saludaron banderas, oyeron la música del himno y recibieron entusiasmados a Gabriel Arias Salgado, al frente del MIT y de esa convención. Según $A B C$, su discurso animó a los agentes de viaje, «servidores nobilísimos de posibilidades crecientes de paz y concordia», a la comunicación entre los pueblos frente al comunismo. E insistió en transformar las imágenes negativas sobre el franquismo en el exterior y a descubrir una España diferente respecto a Europa, civilizadora, anticomunista, y con gentes abiertas y vitales. El ministro invitó a los «profesionales con actitud generosa y noble» a ser testigos de la hospitalidad española, de su riqueza monumental, de climas y regiones variadas. Por fin, puso a la industria del

\footnotetext{
51 VALLEJO PAUSADA, 2019.

${ }^{52}$ La Vanguardia, 11.10.1957. FUENTES VEGA, 2017: 162-163.
} 
turismo como prioridad del régimen, agradeciendo la confianza por sumarse a la celebración del 12 de octubre.

Como respuesta, el embajador norteamericano leyó un mensaje del presidente Dwight Eisenhower en favor de los viajes internacionales. Y animó a visitar España porque, decía Lodge, había maravillas arquitectónicas, obras de arte por descubrir, y seres humanos amigables que necesitaban dólares para vivir mejor si se impulsaba el turismo y el comercio. Otros discursos sellaron la idea. El delegado de la empresa Iberia halagó la contribución de los agentes de viajes al tráfico aéreo y el director general de turismo ofreció hoteles a los congresistas. Según los reporteros, convencidos todos de que los viajes ayudaban a la tolerancia y comprensión de los problemas mundiales, homenajearon a Colón por haber hecho el viaje más importante del mundo ${ }^{53}$. La convención pareció ser exitosa, dado que posteriores informes aconsejaron incrementar el número de visitantes a España. Como potenciales clientes de los vuelos regulares de Iberia entre Nueva York y Madrid, bautizados con los nombres de las carabelas del viaje de Colón, las clases medias europeas y americanas podían participar de la movilidad y el prestigio social viajando al extranjero, retornar a casa con objetos de recuerdo de lugares y pertenecer a una cohorte de turistas internacionales del mundo libre, curiosos por la autenticidad, el carácter, la cultura y las costumbres de las naciones ${ }^{54}$. Entre los españoles, en cambio, en los años cincuenta, los vuelos transatlánticos estaban reservados a unos pocos. Los precios astronómicos animaban a la imaginación a partir de postales y revistas ilustradas ${ }^{55}$. Con todo, el 12 de octubre de 1957 en Madrid había fortalecido el desarrollo profesional del turismo y una internacionalización moderna del nacionalismo español.

\section{El 12 de octubre de 1963 en Tarragona}

El 12 de octubre había sobrevivido a los cambios del calendario festivo decretado por la dictadura a comienzos de 1958, pero se recicló como símbolo cultural para una idea más práctica y regeneradora de España a escala global. El «día de la Raza» había pasado a denominarse «día de la Hispanidad». El cambio de nombre ampliaba y materializaba, especialmente para políticas exteriores del régimen, atributos únicos de la identidad nacional española para promover al Estado franquista como la cabeza de una comunidad iberoamericana de naciones imaginadas unidas por la historia, la cultura, la religión y el lenguaje. Esto facilitaba intercambios, proyectos y realizaciones concretas. La

\footnotetext{
$53 A B C, 15.10 .1957$.

54 ROSENDORF, 2014, cap. 3.

55 BARCIELA, 2013: 148-151.
} 
idea renovada de la hispanidad integraba las posiciones más tradicionales e ideologizadas sobre el 12 de octubre en ensayos de modernización social, económica y política, promovidos y gestionados por tecnócratas católicos y conservadores. Junto con el 18 de julio, celebración que exaltaba el recuerdo del alzamiento militar de 1936, el 12 de octubre seguía teniendo una alta carga diplomática, aún renombrado su significado ${ }^{56}$.

Asimismo, desde 1959 planes de reforma económica en favor de la eficiencia y la administración habían devaluado la peseta y liberalizado un poco el mercado. Las medidas fueron clave para el turismo y animaron a nuevos convenios internacionales y campañas de promoción por Europa, Estados Unidos y América del Sur. Por entonces, España recibía el 6,2\% de ingresos del turismo internacional y una cuota aproximada de 4 millones de turistas. Las medidas favorecieron la expansión de turoperadores británicos y alemanes que organizaban vacaciones a europeos y americanos. Las reformas también alentaron inversiones en transporte, construcción y hostelería. Y acabaron marcando la geografía de la expansión turística en las islas Canarias, Baleares y otros enclaves del Mediterráneo. El 12 de octubre se actualizó para los inicios del boom turístico español.

De hecho, desde los años cincuenta algunas zonas de Cataluña, como la Costa Brava y Tarragona, se habían abierto al negocio del turismo. Localidades con sol y playa, clima benigno y patrimonio cultural habían atraído a operadores e inversores extranjeros para viajes e instalaciones hoteleras ${ }^{57}$. La proximidad con la Europa industrializada, el desarrollo del transporte y las políticas públicas locales habían fomentado el crecimiento de actividades, intermediarios y empresas, favoreciendo la alta especialización de determinadas geografías en el turismo. Con las reformas de apertura en marcha, el turismo se había convertido, en los años sesenta, en pieza clave de la transformación económica española. Con un ritmo de crecimiento superior a cualquier otro país europeo, España fue un destino preferido de la Europa mediterránea para el placer de las vacaciones. La llegada de visitantes impactó en el paisaje natural y humano de regiones y ciudades costeras fácilmente expuestas a los servicios del sector ${ }^{58}$.

Ese impulso renovador resultó de la gestión de Manuel Fraga al frente del MIT, entre 1962 y 1969. El joven diplomático, con un inglés fluido y experiencia previa en el ICH, el Instituto de Estudios Políticos y el Ministerio de Educación, no representaba a los tecnócratas más duros del Opus Dei. Sus decisiones recogieron recomendaciones del Banco Mundial, propiciando el crecimiento del turismo y su rentabilidad política dentro y fuera de España. Se reorganizaron competencias territoriales y se reformó en favor de trámites aduaneros y de visados más ágiles, inversiones extranjeras más fáciles, y el

\footnotetext{
${ }^{56}$ DA SILVA: 1999-2000: 135-148.

57 VALLEJO POUSADA, 2015. PACK, 2009: 121-129. MORENO GARRIDO, 2007: 208-213.

${ }^{58}$ MALUQUER DE MOTES, 2011. CALS, 1982.
} 
control de las empresas públicas. También se asoció la gestión del turismo con otros ministerios y gobiernos locales desbordados por los efectos económicos y sociales del negocio, pero sin descentralizar funciones y mitificando la cultura popular. La política oficial del turismo entonces quedó relacionada con la gestión cultural, la propaganda y el control de los medios de comunicación ${ }^{59}$.

En sintonía con el Ministerio de Exteriores se promocionó una imagen moderna de España entre nuevos sectores de sociedades europeas y americanas. La amistad con Estados Unidos había orientado las energías políticas y las campañas de publicidad especialmente en favor del turismo por la geografía española, la moda, la industria del cine, y las relaciones públicas con políticos, periodistas y diplomáticos. Conforme se recibían créditos, se procuraba llegar a nuevos públicos, atraer turistas y ganar apoyos. Algunos tópicos del pasado sostuvieron el envite diplomático; entre ellos, la participación española en la configuración del nuevo mundo y en la independencia de las colonias británicas en Norteamérica. Los temas modernos, como la tecnología puntera de telecomunicaciones por satélite, también reforzaron los negocios entre España y Estados Unidos $^{60}$.

La propaganda turística y el ambicioso programa de relaciones públicas y diplomáticas pusieron en funcionamiento una idea de Estado-nación con encaje de la cultura, la economía y las instituciones de las regiones españolas. El modelo también servía para imaginar una identidad colectiva asentada en un equilibrio entre la diversidad regional y la unidad nacional como justificación de las jerarquías de una administración centralizada desde Madrid. Esa interpretación explica, por ejemplo, la acelerada promoción, desde 1962, del Camino de Santiago como símbolo para el prestigio internacional de España o el apoyo a las propuestas de asociar los días de la Hispanidad de 1960 y 1963, en Palma de Mallorca y Tarragona, con el turismo. El 12 de octubre también aludía a diversidad y funcionó como un producto para la difusión de las identidades nacionales, regionales, locales e internacionales.

La iniciativa de acoger en Tarragona el Día de la Hispanidad en 1963 había salido del poder franquista local. La Iglesia convenció al ministro Castiella de hacer coincidir el festejo con la invención del centenario paulino, los 1.000 años de la capitalidad de la ciudad, y la buena marcha del turismo en la zona ${ }^{61}$. La idea entusiasmó a quienes reunían cada año a diplomáticos hispanoamericanos y personalidades para actos religiosos y académicos. Además, encajaba con otras iniciativas públicas de alcance internacional para contrarrestar la mala imagen del régimen

59 CALS, 1974: 25. REY REGUILLO, 2017. POULET, 1995.

${ }^{60}$ ROSENDORF, 2014: 90-91.

${ }^{61}$ Carta al ministro Castiella al gobernador civil de Tarragona, Rafael Fernández Martínez (29.05.1963), AGA, DGPE, expediente R. 7166/23, Conmemoración en España de la Fiesta de la Hispanidad. 
que habían provocado en Europa los procesos judiciales contra antifranquistas y, especialmente, la ejecución del dirigente comunista Julián Grimau el 20 de abril de ese año ${ }^{62}$. El auge del turismo en la Costa Brava había animado al ICH a codificar recuerdos para el Día de la Hispanidad y focalizar iconos culturales de Tarragona para la imaginación colectiva como uno de los lugares únicos y típicos identificados con las esencias del ser nacional.

En efecto, la fiesta itinerante del 12 de octubre por la geografía española estaba consolidada como un producto cultural más del franquismo desarrollista para el consumo de la diversidad regional entre la población local y los visitantes nacionales y extranjeros. La celebración se organizó en 1963 en torno al patrimonio cultural urbano, un pasado conservado y la modernización de la región. Se utilizó la geografía, la historia y la herencia cultural de una ciudad de la costa privilegiada del Mediterráneo para reproducir ambientes visibles al ocio y una oferta turística amplia. Con la fiesta, el Estado gestionó la idea de que lo tradicional atraía a visitantes foráneos, generaba beneficios económicos y facilitaba la identificación local con la identidad nacional.

El festejo itinerante, integrado en las políticas del turismo, servía como vehículo de identidad nacional española, facilitando imágenes únicas entre diplomáticos y demás consumidores de espacios y pasados transmitidos. El programa festivo fundía las señales modernas del turismo con la herencia cultural e histórica del pasado mediante la exhibición de monumentos, patrimonio arquitectónico, costumbres, tradiciones y folklore regional. La idea de nación, gestionada con la fiesta y para el turismo, transmitía un pasado versátil mientras promovía las esencias de paisajes únicos de un territorio periférico como un producto mediterráneo español para los negocios y el placer internacional ${ }^{63}$. Como artefacto cultural que desempolvaba tradiciones para renovados propósitos, la celebración fomentaba el turismo y cultivaba la imaginación de autoridades, visitantes y católicos. Asimismo, facilitaba la construcción de narrativas nacionales.

De hecho, la imaginación nacionalcatólica había inventado el 12 de octubre para fechar el desembarco del santo Pablo en el puerto de la ciudad imperial de Tarraco mil años antes para pregonar las nuevas ideas cristianas entre legiones del Mediterráneo. El año santo se había inaugurado en Tarragona a comienzos de 1963 con autoridades, actos católicos, publicaciones, monumento al santo, homenajes a deportistas, representaciones teatrales y peregrinaciones de sindicalistas y colectivos afectos al régimen. Ese 12 de octubre de 1963 se ideó como el día grande para celebrar el milenario de una ciudad con una costa privilegiada, clima agradable y un pasado legendario. Se promocionaron sus balnearios naturales para el turismo internacional desde la antigüedad y se actualizó su historia hecha

\footnotetext{
${ }^{62}$ MATEOS, 2014: 142-144. AGUILAR FERNÁNDEZ, 2008: 187-189.

${ }^{63}$ AFINOGUÉNOVA, 2011.
} 
a capas. De origen prerromano a colonia y capital del imperio con puerto clave del Mediterráneo; de ciudad medieval a centro eclesiástico de la corona de Aragón ${ }^{64}$.

Hecha y deshecha por romanos, visigodos, musulmanes y cristianos, la ciudad conservaba restos arqueológicos, edificios y monumentos públicos para la memoria y el disfrute de visitantes y turistas. El patrimonio cultural de la región aportaba a la identidad nacional vestigios de anfiteatros, torres funerarias, acueductos, arcos, iglesias, murallas, patios de nobles, foros de comercio, óleos y tapices. Los organizadores de la fiesta recurrían a la herencia y paisajes únicos para codificar la identidad regional e integrarla en la narración sobre la diversidad territorial en la unidad nacional ${ }^{65}$. Según ilustraban, Tarragona aportaba cualidades específicas para la imaginación colectiva y prácticas cosmopolitas. La ciudad y la región habían sido focos de difusión de ideas y costumbres hispanas y, a su vez, lugares de origen y paso de extranjeros en el imperio romano. Hispanizar lo latino era tradición de ese espacio. El carácter de esa geografía había sido moldeado por un puerto donde habían desembarcado mercancías, viajantes y embajadores desde la antigüedad ${ }^{66}$.

La modernidad, ante un mar Mediterráneo que bañaba playas de arena dorada y pinos, también aportaba rasgos únicos a Tarragona. El turismo había traído progreso y apertura, decían los promotores de la celebración. La ciudad se había transformado, disponiendo de calles anchas, edificios modernos, comercios lujosos, una universidad laboral, y proyectos de industrialización agrícola. Las urbanizaciones edificadas en la ribera del Mediterráneo y la gastronomía de su barrio marítimo mutaban en favor del turismo. Los turistas aportaban a la construcción y difusión de la identidad regional integrada en una unidad imaginada más amplia consumiendo comidas, artesanía y tradiciones festivas locales en terrazas, tiendas y espacios públicos tras jornadas de sol y playa. Contribuían a la imagen de una España alegre y de faldas cortas pero, a su vez, portadora de herencia cultural.

Interpretadas como contribuciones desde abajo, el franquismo desarrollista explotaba el folklore y lo exótico como nexo entre lo tradicional y lo moderno. La exaltación de las costumbres regionales servía para difundir las diversidades culturales y geográficas complementarias para la identidad nacional ${ }^{67}$. Eficaces vehículos de integración y productos para campañas comerciales gestionadas desde el poder, en los años sesenta ayudaron a fabricar estereotipos desde afuera $^{68}$. En Tarragona y otras ciudades cercanas como Reus, Tortosa o centros de veraneo como Calafell, Cambrills, Salou y San Carlos la Rápita, las torres

\footnotetext{
${ }^{64}$ Mundo Hispánico, 187, 1963: 18-20.

65 AFINOGUÉNOVA, 2010. STORM, 2013.

${ }^{66}$ Mundo Hispánico, 187, 1963: 21-27.

${ }^{67}$ NÚNEZ SEIXAS, 2009.

${ }^{68}$ STORM, 2014. FUENTES VEGA, 2017.
} 
humanas de los castellers, la sardana, los toros y otras tradiciones típicas estaban a disposición de habitantes locales, turistas y visitantes. Una Tarragona bicéfala representaba a la nación el 12 de octubre de 1963. Una milenaria y otra cosmopolita, congregando piedras romanas, construcciones medievales y rascacielos, y descubriéndose como una capital mediterránea para el turismo internacional ${ }^{69}$.

La puesta en escena del 12 de octubre de 1963 tuvo Te Deum y acto académico, como era habitual. También, otras actividades animaron la sociabilidad diplomática. Franco y Castiella no fueron anfitriones en Tarragona. Tampoco el ministro de Educación, Lora Tamayo, que ese día presidió la inauguración de la Facultad de Derecho de Valencia con estudiantes franquistas favorables a una reforma universitaria en medio de coloridas banderas y sonidos de trompeta y $\operatorname{misa}^{70}$. El director del ICH, Gregorio Marañón Moya, presidió los actos institucionales. Un cardenal de Tarragona llegado desde Roma, Benjamín De Arriba y Castro, se encargó de la liturgia religiosa en compañía de autoridades y diplomáticos de Portugal, Estados Unidos y los países latinoamericanos, excepto Argentina. El Palacio Municipal acogió el acto académico, flanqueado por banderas de España y los Estados representados. Se recordó a Zacarías de Vizcarra como autor de la idea de Hispanidad muerto ese año, se entregaron premios y sonaron discursos providencialistas sobre Tarragona como vía de acceso al cristianismo y otros, más proyectivos, sobre intercambios culturales y académicos.

Fото 2. 12 de octubre en Tarragona, 1963

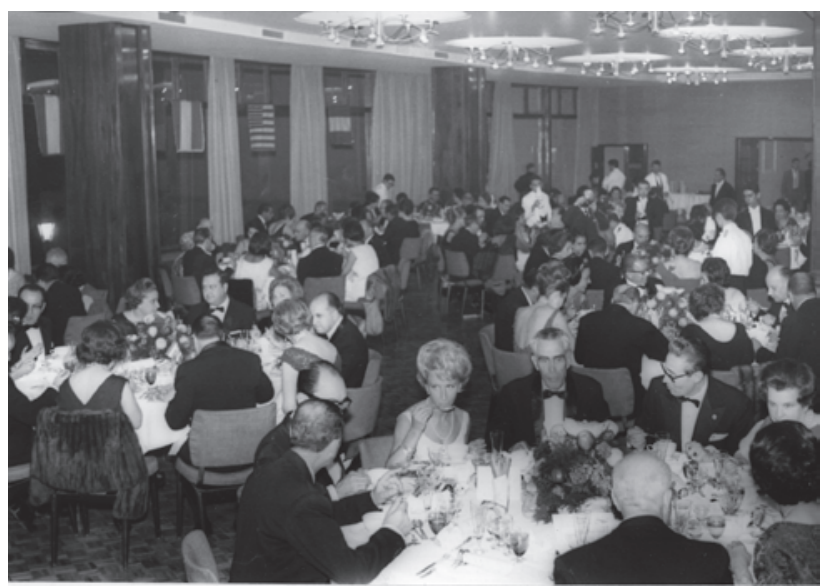

Fuente: Archivo Fotográfico Mundo Hispánico, Agencia Española de Cooperación Internacional para el Desarrollo, Biblioteca.

\footnotetext{
${ }^{69}$ Mundo Hispánico, 187, 1963: 8-17. PACK, 2009: 218.

$70 A B C, 11.10 .1963$, AJL, FJM.
} 
La celebración cultivó la sociabilidad diplomática durante comidas ofrecidas por empresarios hoteleros afectos al régimen, conciertos de orfeones en restos arqueológicos, representaciones de ballet, películas sobre misioneros en América, y paseos. Para los asistentes, como si fueran turistas, se organizó el programa de festejos con visitas al patrimonio cultural conservado en monumentos, ciudades y paisajes como los monasterios de Santes Creus, de Poblet, las poblaciones de Reus o Valls, donde fueron recibidos con la actuación de los xiquets construyendo torres humanas y otras representaciones folklóricas. También, en los paseos se incluyó a las urbanizaciones de Salou y Cambrils, reflejando la expansión turística moderna e imágenes menos románticas y bucólicas de la nación ${ }^{71}$.

Fото 3. 11 de octubre en el Palacio Municipal de Valls, Tarragona, 1963

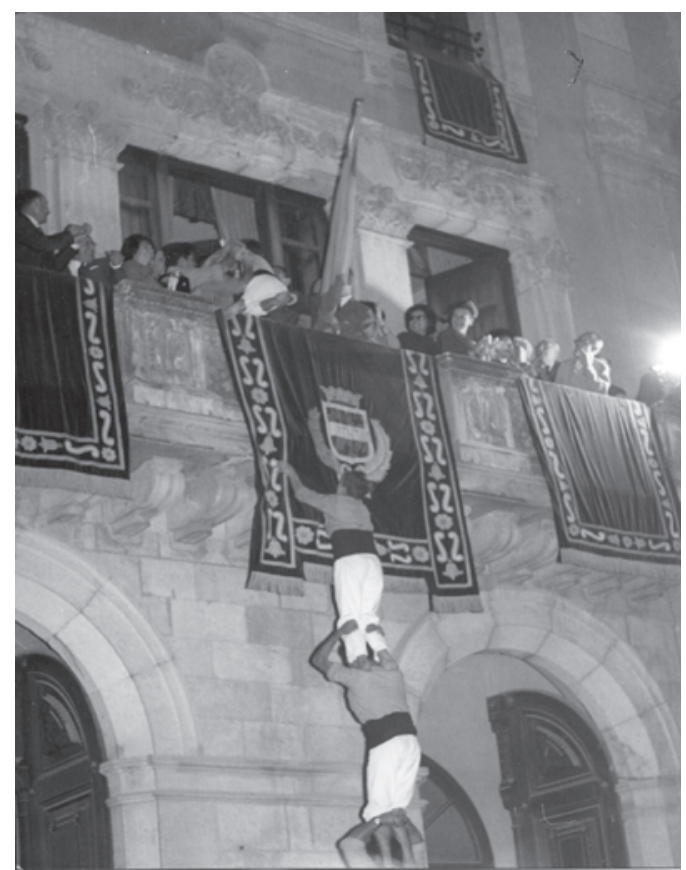

Fuente: Archivo Fotográfico Mundo Hispánico, Agencia Española de Cooperación Internacional para el Desarrollo, Biblioteca.

La colaboración entre política exterior, turismo y poder local para el 12 de octubre se dejó ver, en 1963, también en Barcelona. El MIT escenificó la

71 Mundo Hispánico, 188, 1963: 52-56. «Día de la Hispanidad en Tarragona», http://www.rtve.es/filmoteca/no-do/not-1085/1469042/ 
función caritativa del festejo y apoyó una gala benéfica para el hospital de la ciudad organizada por los industriales de la seda en el Palacio de Montjuich, donde jóvenes muchachas exhibieron sus mejores galas ${ }^{72}$. Por su parte, el ICH se sumó al homenaje a Juan Maragall organizado en la ciudad con conferencias, juegos florales y la inauguración de un monumento en su honor. Halagó al periodista y escritor en español y catalán, repasando su deriva del liberalismo al nacionalismo sin dejar de pertenecer a la burguesía industrial catalana ${ }^{73}$. En Madrid, el símbolo recordado acaparó la atención de varios colectivos y tuvo componentes de internacionalismo. Se escenificaron los tradicionales honores religiosos y hubo gestos de identificación de profesionales y deportistas aventureros con el festejo. Tampoco faltó el habitual homenaje que hacían militares de Massachusetts desde los acuerdos firmados con Estados Unidos. La policía de circulación puso en común su hacer mientras que los ciclistas animaron un campeonato de regiones para hacer conocer la diversidad en la unidad. El día había sido elegido, también, para reunir en un congreso a cerca de 6.000 excombatientes europeos en el Valle de los Caídos, que pedían privilegios corporativos. Hicieron ruido y alarde de anticomunismo, pero poco más ${ }^{74}$. Finalmente, para la ocasión se hicieron públicos los progresos en favor de la cooperación para un bienestar posible de emigrantes europeos. Se firmó un acuerdo hispano-francés ratificando subsidios para familiares de trabajadores franceses y españoles ocupados en uno de los países ${ }^{75}$.

Fuera de España, las embajadas fomentaron la celebración. Como era costumbre desde los años cincuenta, en Londres, París, Roma y Lisboa se ofrecieron recepciones a diplomáticos iberoamericanos. El despliegue conmemorativo para el 12 de octubre de 1963 había sido especialmente orquestado en Estados Unidos. Por entonces, se estaban renovando los acuerdos bilaterales económicos y militares que habían dado un respiro a la dictadura de cara a la preparación del plan de estabilización económica de $1959^{76}$. Castiella habló en la OEA para el Día de la Hispanidad como refuerzo de la política exterior del franquismo. El ministro recordó ante los embajadores americanos al teólogo Francisco de Vitoria como fundador del Derecho internacional y del pacifismo mundial ${ }^{77}$. Y escenificó su discurso entregando un busto en su honor conforme a lo dispuesto en la VII Conferencia Panamericana de Montevideo, en 1933. La diplomacia española se ofrecía al entendimiento interamericano en plena

${ }^{72} A B C, 13.10 .1963$.

${ }^{73}$ Gregorio Marañón, «Juan Maragall y la hispanidad», Conferencia en homenaje a Maragall organizada por el Ayuntamiento de Barcelona, octubre de 1963.

${ }^{74} A B C$, 13.10.1963: 8-9. ALCALDE, 2014: 325-326.

${ }^{75} A B C, 13.10 .1963$.

76 Informaciones (Madrid), 28.09.1963, AJL, FJM.

77 SCARFI, 2014.

Hispania, 2021, vol. LXXXI, n. ${ }^{\circ}$ 267, enero-abril, págs. 195-226, ISSN: 0018-2141, e-ISSN: 1988-8368 https://doi.org/10.3989/hispania.2021.007 
Guerra Fría y al desencaje producido por la revolución cubana. Había sido América, decía, el sostén de la arquitectura jurídica desarrollada desde Salamanca y continuada por discípulos del humanista europeo. La OEA ratificó entonces el pensamiento del dominico como pilar del sistema interamericano porque conjugaba las corrientes jurídicas de origen latino y sajón para la igualdad entre Estados, la cooperación internacional y la comunicación pacifista ${ }^{78}$. Tanto ruido había generado la diplomacia española para el 12 de octubre en algunas ciudades norteamericanas que hasta el presidente John F. Kennedy se unió al recuerdo, recibiendo en los jardines de la Casa Blanca a asociaciones de emigrantes españoles y su descendencia ${ }^{79}$.

\section{Conclusiones}

La celebración del 12 de octubre, que había participado de todas las ofensivas diplomáticas del siglo XX, se recicló durante el franquismo conciliando nacionalismo e internacionalismo, tradicionalismo y modernidad. La dictadura utilizó la fiesta para recomponer su imagen y reputación en el mundo durante la Guerra Fría, especialmente con Estados Unidos, América Latina y Europa. Los festejos escenificaron las fórmulas del poder blando de la cultura para el intercambio internacional. En los años cincuenta y sesenta, el turismo también participó en la celebración, reforzando su carácter cívico sin restar protagonismo a la Iglesia. Diplomáticos, profesionales y viajeros fueron protagonistas de actos, paseos y congresos organizados por la administración para exhibir, con el festejo, una identidad turística española.

El franquismo hizo de la fiesta un escaparate para mejorar su imagen y la publicidad del carácter exótico y diferencial de España en el mapa europeo. El carácter itinerante del festejo se dispuso para la construcción y transmisión de imaginarios sobre lugares y registros culturales únicos. Sin ser popular, el despliegue del 12 de octubre por diferentes ciudades fijó geografías para una idea de España y su proyección exterior. La fiesta, incorporando el turismo para su puesta en escena en territorios insulares periféricos y de la costa mediterránea, servía para la conformación de opinión y la difusión del tipismo, el folklore regional, los paisajes naturales y las ventajas del sol y la playa entre diplomáticos y visitantes extranjeros. Después de todo, el turismo era un instrumento de comunicación para las relaciones internacionales.

Las celebraciones en Canarias y Tarragona proporcionaban imágenes de naturaleza, cultura, patrimonio histórico y modernidad estimulantes para el turismo. Aún con protocolo, la fiesta mostraba la diversidad del territorio, las

\footnotetext{
${ }^{78} A B C, 9.10 .1963$, AJL, FJM.

79 Mundo Hispánico, 188, 1963.
} 
instituciones y a los propios españoles como parte de una unidad que debía ser vista desde fuera y consumida desde dentro. Esos festejos, y los de Barcelona, ponían en escena símbolos, arte, cultura y costumbres de territorios periféricos al margen de un nacionalismo español identificado exclusivamente con Castilla y Andalucía. En Madrid se asoció el símbolo con el pragmatismo desarrollista. Si bien no era cosa nueva la promoción del regionalismo cultural, el franquismo mostró la diversidad española dentro de la unidad entre visitantes dispuestos a absorber tradición y un cosmopolitismo iberoamericano.

La incorporación del turismo al 12 de octubre agregó nuevos registros a un producto inventado desde la propaganda oficial, el cine y la publicidad sobre lugares típicos de España, aderezado de ideología nacionalista, católica o modernizadora. Hasta la Iglesia se sumó al despliegue porque renovaba su misión pastoral, preservando su patrimonio religioso y exhibiendo el espectáculo de la liturgia tradicional para actividades modernas. Así, la geografía y la historia facilitaban la invención de imaginarios para el recuerdo y la proyección de lugares emblemáticos poco conocidos. Y las celebraciones fueron un estímulo para prácticas de sociabilidad y consumo. Por su carácter diplomático y cosmopolita, la fiesta definió el estado de las relaciones internacionales y el lugar de España en el mundo a lo largo del siglo XX. Desde su institucionalización, en 1918, su puesta en escena había sido un sofisticado ritual de Estado que demarcaba honorabilidad, distinción y elitismo. También, en los años cincuenta y sesenta, cada 12 de octubre era un espacio para las relaciones públicas entre diplomáticos, visitantes de gobiernos extranjeros y, ocasionalmente, de profesionales vinculados a la educación, la gestión política local, el turismo y otros sectores profesionales. En medio de paseos, bailes, misas, exhibiciones de danza o coros, películas y discursos, a veces interminables, se establecieron relaciones personales y se practicó una sociabilidad informal que generó imágenes y opiniones. La fiesta era un microcosmos de cosmopolitismo iberoamericano que ponía en marcha proyectos internacionales para la regeneración nacional.

\section{Bibliografía}

Afinoguénova, Eugenia, «'Unity, stability, continuity': Heritage and the renovation of Franco's dictatorship in Spain, 1957-1969», International Journal of Heritage Studies, 16/6 (London, 2010): 417-433.

Afinoguénova, Eugenia, «Lo moderno y lo primitivo en la industria del patrimonio desarrollista, 1962-1969», en Rosalía Cornejo Parriego y Alberto Villamandos, Un hispanismo para el siglo XXI: Ensayos de crítica cultural, Madrid, Biblioteca Nueva, 2011: 159-181.

Hispania, 2021, vol. LXXXI, n. ${ }^{\circ}$ 267, enero-abril, págs. 195-226, ISSN: 0018-2141, e-ISSN: 1988-8368 
Afinoguénova, Eugenia, «El discurso del turismo y la configuración de una identidad nacional para España», en Antonia del Rey Reguillo (ed.), Cine, imaginario y turismo. Estrategias de seducción, Valencia, Tirant lo Blanch, 2017: 35-63.

Aguilar Fernández, Paloma, Politicas de memoria y memorias de política, Madrid, Alianza Editorial, 2008.

Alares López, Gustavo, Políticas del pasado en la España franquista (1939-1964). Historia, nacionalismo y dictadura, Madrid, Marcial Pons, 2017.

Alcalde, Ángel, Los excombatientes franquistas: la lucha de la guerra del fascismo español y la Delegación Nacional de Excombatientes (1936-1965), Zaragoza, PUZ, 2014.

Arenal, Celestino del, La politica exterior de España hacia Iberoamérica, Madrid, Editorial Complutense, 1994.

Barciela, Carlos, Recuerdo del Madrid de la postguerra, Alicante, Universidad de Alicante, 2013.

Barrachina, Marie-Aline, «Fiesta de la raza, Día de la Hispanidad, Día del Pilar, Fiesta nacional», Bulletin d'Histoire contemporaine de l'Espagne, 30/31 (Talence, 1999-2000): 119-134.

Box, Zira, «El nacionalismo durante el franquismo (1939-1975)», en Antonio Morales Moya, Juan Pablo Fusi y Andrés de Blas Guerrero, Historia de la nación y del nacionalismo español, Madrid, Galaxia Gutenberg, 2013: 903-920.

Cals, Joan, Turismo y política turística en España, una aproximación, Barcelona, Ariel, 1974.

Cals, Joan, La costa brava i el turismo. Estudies sobre la política turística, el territorio y l'hoteleria, Barcelona, Kapel, 1982.

Campos Pérez, Lara, Celebrar la nación. Conmemoraciones oficiales y festejos durante la segunda República, Madrid, Marcial Pons, 2016.

Cenarro, Ángela, «Los días de la "Nueva España": entre la "revolución nacional” y el peso de la tradición», Ayer, 51 (Madrid, 2003): 115-134.

Correyero Ruiz, Beatriz, «La propaganda turística española en los años de aislamiento internacional», Historia y comunicación social, 8 (Madrid, 2003): 47-61.

Crónica del VI congreso histórico municipal interamericano, Madrid-Barcelona, 1957, Madrid, Instituto de Estudios de Administración Local, 1958.

Crumbaugh Justin, Destination dictatorship: the spectacle of Spain's tourist boom and the reinvention of difference, Albany, State University of New York Press, 2009.

Da Silva, Irene, «La législation franquiste et les fêtes», Bulletin d'Histoire Contemporaine de l'Espagne, 30-31 (Aix-en-Provence, 1999-2000): 135-148.

Delgado Gómez-Escalonilla, Lorenzo, Imperio de papel. Acción cultural y política exterior durante el primer franquismo, Madrid, CSIC, 1992.

Duarte, Ángel, «El municipio republicano: sostén de la democracia y refugio de la tempestad (Algunas consideraciones catalanas y ampurdanesas)», en Carlos Forcadell y María Cruz Romeo (eds.), Provincia y nación. Los territorios del liberalismo, Zaragoza, Institución Fernando el Católico/Diputación de Zaragoza, 2006: 101-119. 
Endy, Christopher, Cold War Holidays: American Tourism in France, Chapel Hill, University of North Carolina Press, 2004.

Escudero, María, El Instituto de Cultura Hispánica, Madrid, Mapfre, 1994.

Ferrary, Álvaro, El franquismo: minorías políticas y conflictos ideológicos, 19361956, Pamplona, Eunsa, 1993.

Fuentes Vega, Alicia, Bienvenido Mr. Turismo. Cultura visual del boom en España, Madrid, Cátedra, 2017.

García Cárcel, Ricardo, La herencia del pasado. Las memorias históricas de España, Barcelona, Gutenberg, 2011.

García Sebastiani, Marcela, "América y el nacionalismo español: las fiestas del 12 de octubre, del franquismo a la democracia», Historia y Política. Revista de Historia de las ideas y los movimientos sociales, 35 (Madrid, 2016): 71-94.

García Sebastiani, Marcela y Marcilhacy, David, «Celebrating the nation: 12 October, from 'Day of Race' to Spanish National Day», Journal of Contemporary History, 52/3 (London, 2017): 731-763.

Giménez Martínez, Miguel Ángel, El Estado franquista. Fundamentos ideológicos, bases legales y sistema institucional, Madrid, CEPC, 2014.

González Calleja, Eduardo y Limón Nevado, Feres, La Hispanidad como instrumento de combate. Raza e Imperio en la prensa franquista durante la guerra civil española, Madrid, CSIC, 1988.

Hispán Iglesias de Ussell, Pablo, La politica en el régimen de Franco entre 1957 y 1969. Proyectos, conflictos y luchas por el poder, Madrid, CEPC, 2006.

Humlebaek, Carsten, Inventing the nation. Spain, London, Bloomsbury, 2015.

Iriye, Akira, Cultural Internationalism and World Order, Baltimore, John Hopkins University Press, 1997.

Juliá, Santos, Historias de las dos Españas, Madrid, Taurus, 2004.

Larrinaga, Carlos y Vallejo Pousada, Rafael, «El turismo en el desarrollo español contemporáneo», [TST] Transportes, Servicios y Telecomunicaciones, 24 (Madrid, 2013): 12-29.

Maluquer de Motes, Jordi, «El turismo, motor fundamental de la economía de Cataluña (1951-2010)», Historia Contemporánea, 42 (Bilbao, 2011): 347-399.

Mateos, Abdón, Historia del antifranquismo: historia, interpretación y uso del pasado, Barcelona, Flor del Viento, 2014.

Molinero, Carme e Ysás, Pere, La cuestión catalana: Cataluña en la transición democrática, Barcelona, Crítica, 2014.

Moreno Garrido, Ana, Historia del turismo en España en el siglo XX, Madrid, Síntesis, 2007.

Moreno Garrido, Ana y Villaverde, Jorge, «De un sol a otro: turismo e imagen exterior española (1914-1984)», Ayer, 14 (Madrid, 2019): 95-121.

Moreno Luzón, Javier y Núñez Seixas, Xosé M., Los colores de la patria. Símbolos nacionales en la España contemporánea, Madrid, Tecnos, 2017.

Noticia histórica sobre Villa y Corte: VI congreso histórico municipal interamericano, Madrid, Artes Gráficas Municipales, 1955.

Núnez Seixas, Xosé Manoel, «El nacionalismo español regionalizado y la invención de identidades territoriales, 1960-1977», Dossier ¿Una patria invisible? El

Hispania, 2021, vol. LXXXI, n. ${ }^{\circ}$ 267, enero-abril, págs. 195-226, ISSN: 0018-2141, e-ISSN: 1988-8368

https://doi.org/10.3989/hispania.2021.007 
nacionalismo español durante la Transición (1975-1982), Historia del Presente, 13 (Madrid, 2009): 55-70.

Nye, Joseph, Jr., Soft power. The means to success in world politics, New York, Public Affairs, 2004.

Nye, Joseph, Jr., The future of power, New York, Public Affairs, 2011.

Pack, Sasha, La invasión pacifica. Los turistas y la España de Franco, Madrid, Turner, 2009.

Pack, Sasha, «Revival of the Pilgrimage to Santiago de Compostela: The Politics of Religious, National and European Patrimony, 1879-1988», The Journal of Modern History, 82/2 (Chicago, 2010): 335-367.

Pack, Sasha, «Turismo en la Europa de la posguerra: de la diplomacia esterliniana al consumismo de masas», [TST] Transportes, Servicios y Telecomunicaciones, 24 (Madrid, 2013): 138-166.

Pardo, Rosa María, «La etapa Castiella y el final del régimen», en Javier Tussell, Juan Avilés y Rosa María Pardo (eds.), La política exterior de España en el siglo $X X$, Madrid, UNED/Biblioteca Nueva, 2000: 341-369.

Poulet, Hervé, Images touristiques de L'Espagne. De la propaganda politique à la promotion touristique, París, Édicions L'Harmattan, 1995.

Ramón Solans, Francisco J., La Virgen del Pilar dice... Usos políticos y nacionales de un culto mariano en la España contemporánea, Zaragoza, PUZ, 2014.

Rey Reguillo, Antonia del (ed.), Cine, imaginario y turismo. Estrategias de seducción, Valencia, Tirant lo Blanch, 2017.

Rodríguez, Miguel, Celebración de «la raza». Una historia comparativa del 12 de octubre, México, Universidad Iberoamericana, 2004.

Rosendorf, Neal, Franco Sells Spain to America. Hollywood, Tourism and Public Relations as Postwar Spanish Soft Power, Nueva York, Palgrave Mc-Millan, 2014.

Ruiz Carnicer, Miguel Ángel, El sindicato nacional universitario (SEU), 1939-1965. La socialización política de la juventud universitaria en el franquismo, Madrid, Siglo XXI, 1996.

Saz, Ismael, «Mucho más que crisis políticas: el agotamiento de dos proyectos enfrentados», Ayer, 68 (Madrid, 2007): 137-163.

Scarfi, Pablo, El imperio de la ley. James Brown Scoot y la contribución de un orden jurídico interamericano, Buenos Aires, FCE, 2014.

Sepúlveda Muñoz, Isidro, El sueño de la Madre Patria. Hispanoamericanismo y nacionalismo, Madrid, Marcial Pons, 2005.

Stavans, Ian y Jaksíc, Iván, What is la hispanidad? A conversation, Austin, University of Texas Press, 2011.

Storm, Eric, «Una España más española. La influencia del turismo en la imagen nacional», en Javier Moreno Luzón, y Xosé M. Núñez Seixas, Ser españoles. Imaginarios nacionalistas en el siglo XX, Barcelona, RBA, 2013: 530-559.

Storm, Eric, «Overcoming Methodological Nationalism in Nationalism Studies: "The Impact of Tourism on the Construction and Diffusion of National and Regional Identities"», History Compass 12/4 (Nueva Jersey, 2014): 361-373.

Storm, Eric, «Tourism and the Construction of Regional Identities», en Xosé M. Núñez Seixas y Eric Storm (eds.), Regionalism and Modern Europe: Identity 
Construction and Movements from 1890 to the Present Day, Londres, Bloomsbury, 2019: 99-119.

Tébar Hurtado, Javier, Risques, Manel, Marín, Martí y Casanellas, Pau, Gobernadores. Barcelona en la España franquista (1939-1977), Granada, Comares, 2015.

Vallejo Pousada, Rafael, «¿Bendición del cielo o plaga? El turismo en la España franquista, 1939-1975», Cuadernos de Historia Contemporánea, 37 (Madrid, 2015): 89-113.

Vallejo Pousada, Rafael, «Turismo en España durante el primer tercio del siglo XX: la conformación de un sistema turístico», Ayer, 14 (Madrid, 2019): 175-211.

Ward, Evan, Packaged Vacation. Tourism Development in The Spanish Caribbean, Gainesville, University Press of Florida, 2008.

Zuelow, Eric G., Touring Beyond the Nation. A Transnational Approach to European Tourism History, Surey, Ashgate, 2010.

Recibido: 12/04/2019

Aceptado: 03/04/2020 